\title{
Effects of Tree Stabilization Systems on Tree Health and Implications for Planting Specifications
}

\author{
Kendra J. Labrosse, Robert C. Corry, and Youbin Zheng
}

\begin{abstract}
A tree stabilization system (TSS) is specified to promote stability and maintain tree posture at transplant. However, staking and guying can compromise tree health. The authors of the current study have investigated the effects of such stabilization systems on trees to inform urban forest planting specifications. Visual symptoms for tree health were recorded for 488 trees with and without TSSs in Guelph, Ontario, Canada. Results showing symptoms of stunted growth, death, and pest/disease were fewer on trees observed with TSSs. Health was negatively impacted by TSSs by producing more symptoms of girdled trunks, swelling, and wilting. Trees planted on public land were found to benefit from being stabilized while trees on private land expressed more negative health effects when observed with trunk support. Implications for urban forest professionals include limiting tree stabilization practice to site conditions where their use is warranted along with timely removal.

Key Words. Guying; Staking; Transplant; Trunk Support; Urban Forest.
\end{abstract}

The urban forest includes street trees, park trees, greenspaces, residential land, and public and private spaces with vegetation (Moll 1995). In cities, the forest improves environmental conditions, supports important social functions, and increases the economic value of the community (Bradley 1995). Trees with the greatest value to the urban forest are those that are mature, strong, and healthy. Tree health and longevity can be compromised in many ways, including by common transplant practices. One widely used practice is the use of a tree stabilization system (TSS), such as trunk staking, guying, or root ball anchoring. Stabilization systems are purported to improve root establishment, but can also negatively affect tree health (Johnson 1997; Costello

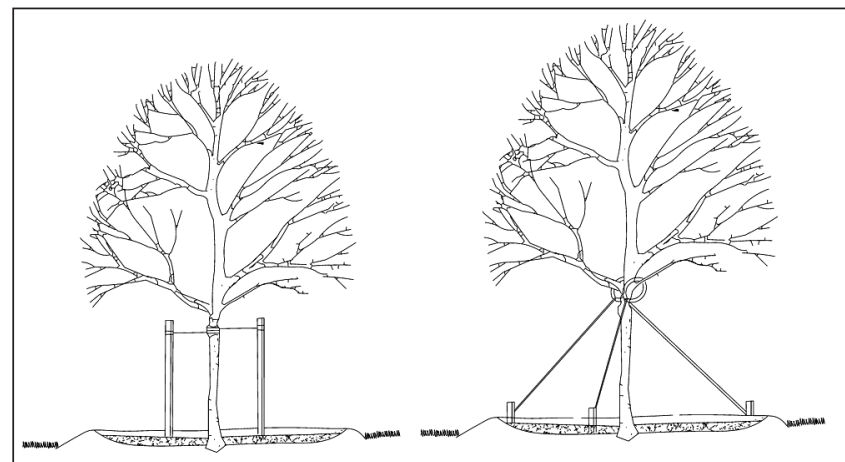

a. b.

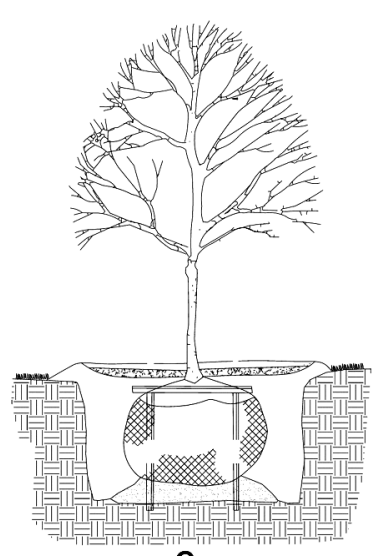

c. et al. 2003; Appleton et al. 2008). Harmful effects range from reduced caliper and trunk taper to trunk deformities to death.

In landscape settings, TSSs are often used during transplant to anchor trees, help establish root system development, provide trunk support, and protect trees from mechanical damage, such as landscaping equipment and vandalism (Patch 1987; Appleton et al. 2008; Eckstein and Gilman 2008; Alvey et al. 2009). The three most common types of TSS are staking, root ball anchoring, and guying (Figure 1). Staking often includes the use of one or two wooden or metal stakes driven into the ground next to the root ball and attached to the trunk with a tether (Figure 1a). Guying involves the use of three or four guylines that are anchored to the ground at an angle and secured by small stakes (Figure 1b) (Lilly 2001). Root ball anchoring is a belowground method of securing the root ball of the tree (Figure 1c). All methods can be fashioned from an assortment of materials.

Research on tree growth and development has been a main focus of study when it comes to TSSs. Studies have compared the effects of different proprietary TSS products to determine which pose fewer negative effects on the growth and development of trees. Research conducted by Svihra et al. (1999), for example, compared three aboveground stabilization products by observing tree growth over a two-year period. One

Figure 1. Common tree stabilization systems: a) staking, b) guying, and c) root ball anchoring. Drawing courtesy of K. Labrosse. year after transplant, the system that allowed for the greatest trunk move- 
ment resulted in development of trees with significantly more taper. Stem taper remained the greatest on these trees even after stabilization systems were removed, demonstrating the importance of trunk movement for adequate taper development.

Appleton (2006) evaluated the response of red maples (Acer rubrum 'Red Sunset') to ten different TSS approaches. The study included a control with no TSS, six aboveground methods, two belowground methods, and one combination below and aboveground method. Markings and damage from the TSSs were observed on tree trunks two years after transplant on trees using aboveground methods. The change in caliper dimension over a one-year period was significantly different among different TSS methods. The least amount of caliper growth was found on a belowground product and the combination, while the greatest growth in caliper was found to be with an aboveground guying method. The study concluded that the different TSS products had little effect on total growth of trees but the longer trees were stabilized, the more serious negative effects on tree health could be observed, emphasizing the importance of removing these systems as soon as the tree's root system is established (Appleton 2006).

Research suggests that TSSs are not necessary in every planting situation. In some cases, TSSs may injure the tree and interfere with growth and development (Harris and Bassuk 1993; Appleton et al. 2008; Eckstein and Gilman 2008; Alvey et al. 2009). Negative effects of TSSs are reduced taper development, increased height growth, decreased caliper growth, trunk deformities, and undesirable water stress responses (Appleton et al. 2008). Multiple studies of TSSs have arrived at similar conclusions with regard to the effects of TSSs on tree development: Jacobs (1954), Harris and Hamilton (1969), Leiser et al. (1972), Wrigley and Smith (1978), Harris (1984), and Patch (1987) have all shown that staking equipment increases tree height, while taper development and caliper growth are decreased. TSSs can cause changes in development because of a lack of movement in the canopy and trunk, which is necessary for proper taper development (Harris and Hamilton 1969).

A TSS can cause morphological injury to trees in addition to causing physiological and developmental changes (Costello et al. 2003). The TSS hardware can girdle trunks, which can then lead to a number of stress-related symptoms. Girdling can impair health, stunt growth, and possibly lead to tree death (Gilman 1997; Johnson 1997; Costello et al. 2003). If the TSS equipment remains on the tree too long then tree vigor may also decline, predisposing the tree to infection (Clark and Matheny 1991).

Researchers agree that in certain instances, transplanted trees may need a stabilization system. These instances include trees with a dense canopy, are located in windy sites, or have poor soil stability (Harris and Hamilton 1969; Appleton et al. 2008). General prescriptions for TSSs should be carefully considered for their effects on tree growth and development (Harris and Bassuk 1993; Appleton et al. 2008). Landscape architects and urban foresters who specify tree planting must ensure the best care and health of the trees as they adjust to their new location. This research aimed to uncover the health effects associated with the use of tree stabilization systems with an observational study based on the literature on TSS effects. Results may help to under- stand TSS effects in different settings and lead to more well-informed establishment of healthy urban forests.

This paper investigates the effects of tree stabilization systems on tree health to improve urban forest planting specifications. The research objectives are:

1. Measure the effects of TSSs on trees through evidence of symptoms

2. Understand the effects of TSSs on tree health-both positive and negative-from literature and analysis of observed symptoms

3. Assess if TSS type or cultural factors change the susceptibility of trees to TSS effects

\section{METHODS}

Urban trees within the City of Guelph provided the basis for investigating the effects of TSSs on tree health. This city is of a representative size and population to other cities in Southwestern Ontario, Canada, and has a population of 118,000 and land area of $86.7 \mathrm{~km}^{2}$. Guelph is located in USDA Hardiness Zone 5a with soils that are dominated by well-drained, slightly basic loams.

\section{Tree Sample}

The study authors randomly selected 488 trees from both public land and recently developed, private land in Guelph, ON. Public sites included parks, stormwater management areas, and public open spaces (five public sites). These trees were recently (2007-2008) planted by private contractors and remained under warranty at the time of study. If specified, the TSS would likely still be in place on these trees. Private sites were generated from a list of site development plans approved by the City of Guelph between 2002 and 2007 and included commercial, residential, industrial, and institutional land uses. Sites within each privately owned land use category were randomly selected to include an equal distribution of sites within each category (20 private sites). No information was available for how long a TSS was on the sampled trees, so the date of city site plan approval is an approximate measure of the time since planting.

\section{Data Collection}

The trees were observed between October 17 and 22, 2009, and information was recorded about the location of the trees, their species, size, the types of TSS used, and any visible health conditions. Tree locations were recorded along with the species to consider any patterns that may make a tree more or less susceptible to the effects of TSSs. Trees were chosen to be visibly representative of site conditions and planting locations. The presence of TSSs was noted along with the materials and method used to stabilize the tree. The diameter at breast height $(\mathrm{DBH})$ was recorded using a handheld caliper. Health defects associated with TSS were categorized under headings of overall health (signs of necrosis or death), crown dieback, girdled trunk, pests or disease (nonspecific), pinched or swollen appearance above the point of constriction, leaf scorch, wilting, stunted growth, flagging, and epicormic sprouting or excessive suckering below the point of constriction (Johnson 1997; Costello et al. 2003). Each symptom was recorded on a scale of one to five, with one indicating severe health problems and five indicating the tree was in good health (Table 1). 
Table 1. Evaluation guide for rating tree health symptoms in the field using visual cues.

\begin{tabular}{|c|c|c|c|c|c|}
\hline \multirow{2}{*}{$\frac{\text { Symptoms }}{\text { Overall health }}$} & \multicolumn{5}{|c|}{ Tree condition score } \\
\hline & 1- dead & 2- declining & 3- injured & 4- struggling & 5- healthy \\
\hline Crown dieback & 1- entire crown & 2- majority & 3- half & 4- some & 5- healthy crown \\
\hline Girdled trunk & 1- entire trunk & 2-majority & 3- half & 4- part & 5- no girdling \\
\hline Swelling & 1- entire trunk & 2- major swelling & 3-minor & 4- beginning & 5- no swelling \\
\hline Leaf scorch & 1- entire canopy & 2- majority & 3-some & 4- occasional & 5- no scorching \\
\hline Wilting & 1- entire canopy & 2-major & 3-some & 4- a few leaves & 5- no wilting \\
\hline Flagging & 1- entire canopy & $\begin{array}{l}\text { 2- many brown } \\
\text { leaves }\end{array}$ & $\begin{array}{l}\text { 3- some brown } \\
\text { leaves drop }\end{array}$ & $\begin{array}{l}\text { 4- occasional } \\
\text { brown leaf }\end{array}$ & 5- normal leaf \\
\hline $\begin{array}{l}\text { Sprouting/ } \\
\text { suckering }\end{array}$ & $\begin{array}{l}\text { 1- greater than } \\
\text { ten suckers }\end{array}$ & $\begin{array}{l}\text { 2- five to nine } \\
\text { suckers }\end{array}$ & $\begin{array}{l}\text { 3- two to four } \\
\text { suckers }\end{array}$ & 4- one sucker & 5- no suckering \\
\hline
\end{tabular}

\section{Data Analysis}

Statistical analysis was performed to test the hypothesis that TSSs have an effect on tree health. The data used for statistical analysis were the symptom values observed on each tree during field investigation (Table 1). Data exploration with JMP (v.8, SAS, Cary, North Carolina, U.S.) indicated that trees in public and private lands responded differently to TSSs and thus they were also analyzed separately.

\section{RESULTS}

\section{Summary Statistics}

Of the 488 trees examined, 247 (51\%) were on public property and $241(49 \%)$ were on private property (Table 2$)$. The sampled trees represented 30 species within 21 genera (Table 3). Three different types of TSSs were recorded: two staking systems and one guying system (Figure 2). The staking systems were common, noncommercial types, using garden hose segments over galvanized wire and two softwood or steel 't-bar' posts (Figure 2a; Figure 2b), which made up 56\% (276 trees) of the sample. The guying system consisted of three hose covered wires anchored to the ground with three short steel stakes (Figure 2c; Figure 2d), but only 3\% (15) trees were found using this method. The remaining $40 \%$ (197) of the trees observed either no longer had or never had a TSS installed (Table 4).

Summarizing the TSS symptom data showed that the majority of trees appeared healthy, with most symptoms indicative of good health (Table 5), illustrating that the trees were generally well-selected for the planting location or well-cared for (or both). The most commonly observed symptom was a girdled trunk with $17.4 \%(n=85)$ of observed trees having at least some girdling. A second symptom that was commonly observed was crown dieback, with $13.7 \%(n=67)$ of trees presenting symptoms. Flagging was not observed in any trees and wilting was observed in only six $(2.1 \%)$ trees. Flagging was omitted from further analysis.

\section{Analysis}

To understand health effects of TSS, health values for the nine symptoms were compared for trees with and without a TSS using the Wilcoxon rank sum method. With all sampled trees, TSSs had significant $(P=0.05)$ effects on five out of nine of the observed symptoms (Table 6). The test found that a girdled trunk, swell-
Table 2. Land ownership and land use of planting locations for 488 trees observed in Guelph, ON.

\begin{tabular}{llc}
\hline Land ownership and use & No. trees sampled \\
\hline Public & SWMF $^{z}$ & 156 \\
& Park & 82 \\
\multirow{4}{*}{ Private } & Open space & 9 \\
& Institutional & 100 \\
& Residential & 53 \\
& Industrial & 64 \\
& Commercial & 24 \\
\hline
\end{tabular}

${ }^{\mathrm{z}}$ Stormwater management facility.

Table 3. Genera of 488 trees observed in Guelph, ON, categorized by xylem class, land ownership, and TSS presence.

\begin{tabular}{lcrrr}
\hline Species & Public land & Private land & TSS & No TSS \\
\hline Diffuse-porous & & & & \\
\hline Acer $(\mathrm{n}=140)$ & 69 & 71 & 62 & 78 \\
Betula $(\mathrm{n}=22)$ & 22 & 0 & 16 & 6 \\
Carpinus $(\mathrm{n}=9)$ & 9 & 0 & 9 & 0 \\
Cercidiphyllum $(\mathrm{n}=3)$ & 2 & 1 & 3 & 0 \\
Malus $(\mathrm{n}=1)$ & 0 & 1 & 1 & 0 \\
Platanus $(\mathrm{n}=7)$ & 6 & 1 & 1 & 6 \\
Pyrus $(\mathrm{n}=11)$ & 0 & 11 & 0 & 11 \\
Syringa $(\mathrm{n}=27)$ & 0 & 27 & 15 & 12 \\
\hline Ring-porous & & & & \\
\hline Celtis $(\mathrm{n}=18)$ & 5 & 13 & 7 & 11 \\
Fraxinus $(\mathrm{n}=43)$ & 11 & 32 & 33 & 10 \\
Gleditsia $(\mathrm{n}=13)$ & 0 & 13 & 7 & 6 \\
Larix $(\mathrm{n}=4)$ & 4 & 0 & 3 & 1 \\
Prunus $(\mathrm{n}=19)$ & 7 & 12 & 9 & 10 \\
Quercus $(\mathrm{n}=39)$ & 30 & 9 & 32 & 7 \\
Tsuga $(\mathrm{n}=1)$ & 1 & 0 & 1 & 0 \\
\hline Coniferous/other & & & & \\
\hline Abies $(\mathrm{n}=13)$ & 13 & 0 & 13 & 0 \\
Amelanchier $(\mathrm{n}=29)$ & 22 & 7 & 16 & 13 \\
Ginkgo $(\mathrm{n}=19)$ & 6 & 13 & 12 & 7 \\
Picea $(\mathrm{n}=28)$ & 16 & 23 & 5 \\
Pinus $(\mathrm{n}=22)$ & 15 & 11 & 17 & 3 \\
Tilia $(\mathrm{n}=20)$ & 9 & & & 11 \\
\hline & & & & \\
\hline
\end{tabular}

ing, and wilting symptoms were significantly worse on trees that were observed with a TSS (Table 6). Symptoms of pests/diseases and death were significantly less common for trees observed with a TSS (Table 6). Stunted growth was almost significant $(P=0.0581)$ and was less severe on trees observed with a TSS. 


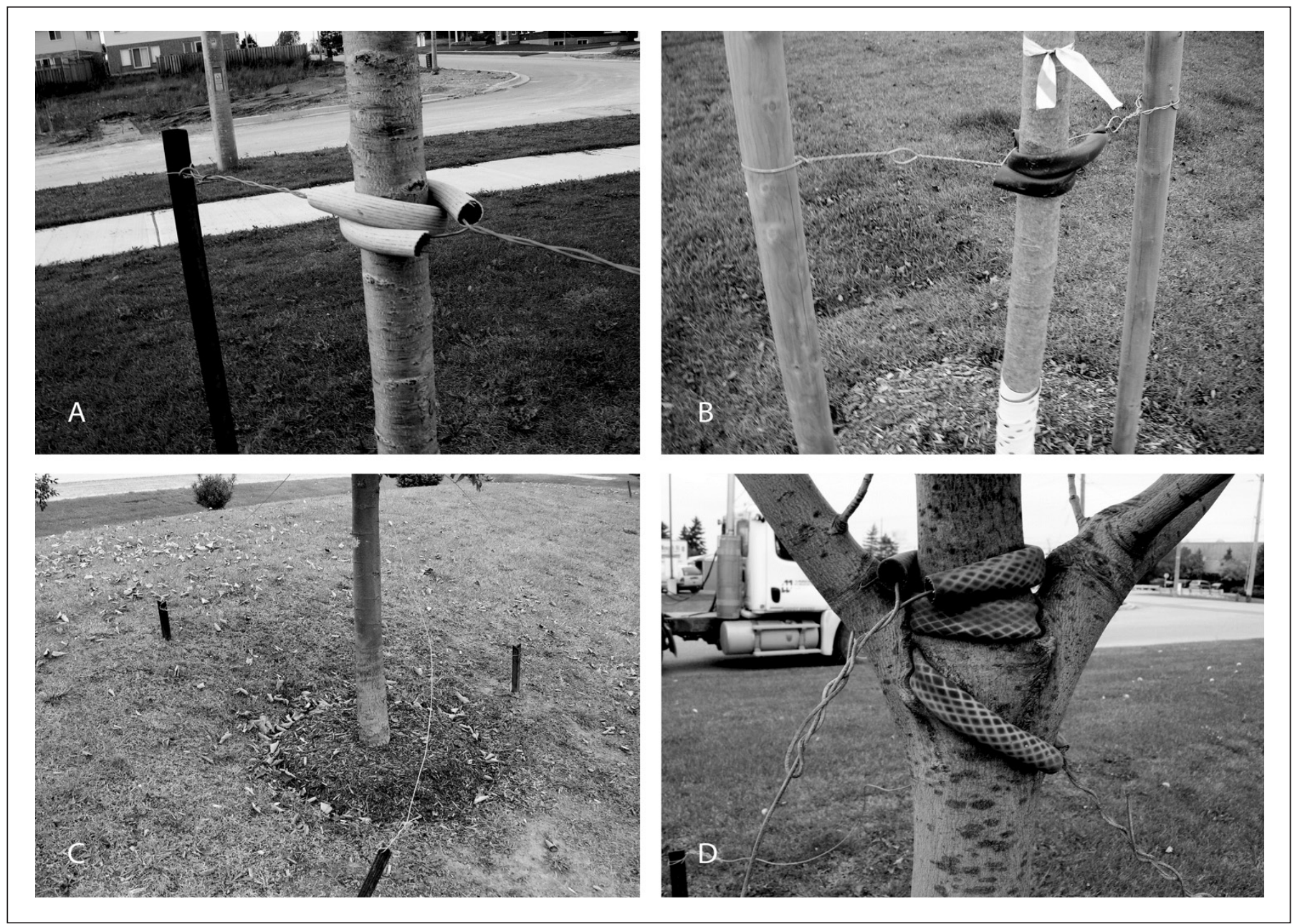

Figure 2.TSS observed during field investigations. a) Metal stakes with a hose-covered wires. b) Wooden stakes with a hose-covered wire. c-d) Guy wires covered with a hose and secured to the ground with small metal stakes. Photographs courtesy of K. Labrosse.

\section{Land Ownership/Use}

For public trees, there was a significant relationship between tree health and TSS for six out of nine symptoms, and only wilting was worse for trees observed with a TSS (Table 7). On public sites, symptoms of death, crown dieback, pests/diseases, stunted growth, and suckering were found to be less severe on trees with a TSS.

For private sites, four out of nine symptoms were significantly different for trees with and without a TSS. Symptoms of crown dieback, girdled trunk, and swell-

Table 4. TSS types observed on trees on public and private lands in Guelph, ON.

\begin{tabular}{lc}
\hline TSS types & No. trees sampled \\
\hline Metal stakes with a hose-covered wire & 241 \\
Wooden stakes with a hose-covered wire & 35 \\
Guy wires & 15 \\
No TSS observed & 197 \\
Total & 488 \\
\hline
\end{tabular}

ing were found to be more severe on private trees observed with a TSS, while symptoms of pests/diseases were found to be less severe on trees observed with a TSS.

Table 5. Number of trees observed in Guelph, ON, displaying varying symptoms of health (from poor (1) to good (5)).

\begin{tabular}{lccccc}
\hline \multirow{2}{*}{ Symptoms } & \multicolumn{5}{c}{ Numbers of trees } \\
\cline { 2 - 6 } & Score 1 & Score 2 & Score 3 & Score 4 & Score 5 \\
\hline Overall health & 1 & 2 & 3 & 12 & 470 \\
Crown dieback & 2 & 8 & 26 & 31 & 421 \\
Girdled trunk & 9 & 6 & 21 & 49 & 403 \\
Pests/diseases & 0 & 4 & 26 & 4 & 454 \\
Swelling & 7 & 5 & 4 & 4 & 468 \\
Leaf scorch & 0 & 4 & 26 & 49 & 409 \\
Wilting & 0 & 0 & 1 & 5 & 482 \\
Stunted growth & 1 & 0 & 2 & 5 & 480 \\
Flagging & 0 & 0 & 0 & 0 & 488 \\
Suckering & 6 & 3 & 4 & 18 & 457 \\
\hline
\end{tabular}

Note: Values are interpreted in Table 1. 
Table 6. Results of comparisons of symptoms for all sampled trees with and without stabilization systems (Wilcoxon rank sum test, $P=0.05, \mathrm{n}=488$ ).

\begin{tabular}{lc}
\hline Symptom & $P$ value \\
\hline Overall health & $0.0072^{\mathrm{z}}$ \\
Crown dieback & 0.2878 \\
Girdled trunk & $0.0158^{\mathrm{y}}$ \\
Swelling & $<0.0001^{\mathrm{y}}$ \\
Pest/disease & $<0.0001^{\mathrm{z}}$ \\
Leaf scorch & 0.0637 \\
Wilting & $<0.0001^{\mathrm{y}}$ \\
Stunted growth & $0.0581^{\mathrm{x}}$ \\
Suckering & 0.2330 \\
\hline${ }^{\mathrm{z}}$ Significantly $(P=0.05)$ less severe on trees observed with a tree stabilization \\
system. \\
${ }^{\mathrm{y}}$ Significantly $(P=0.05)$ more severe on trees observed with a tree stabilization \\
system. \\
${ }^{\mathrm{x}}$ Significantly $(P=0.06)$ more severe on trees observed with a tree stabilization \\
system.
\end{tabular}

\section{DISCUSSION}

Across the entire data set, it was found that trees with a TSSs had significantly fewer symptoms of pests/diseases and diminished overall health; stunted growth was (marginally significantly) reduced. These results indicate that TSSs are associated with improved tree health during the establishment and early post-establishment period in Guelph. The added stability might be helping to compensate for the root loss due to transplanting practices, thus reducing the risk of transplant shock and associated symptoms, which might explain why stunted growth, pests/diseases, and diminished overall health are less common for trees with a TSS in Guelph (conforms to Alvey et al. 2009; Struve 2009). These results concur with those of others regarding the positive effects associated with TSSs relating to tree health by providing added stability to trees in sites that are windy or have unstable soils (Appleton et al. 2008; Eckstein and Gilman 2008; Urban 2008; Alvey et al. 2009). Because newly planted trees on windy sites may be more susceptible to blowing over in strong winds, a TSS can help anchor the root ball while structural roots are still establishing (Appleton et al. 2008). Unstable soil can cause the root ball to shift and can even uproot the tree (Rahardjo et al. 2009).

Negative health symptoms have also been connected with the use of a TSS. Girdling of the trunk, swelling above the point of constriction, and wilting were observed to be worse on trees with a TSS in this research. These are common, vivid symptoms associated with TSSs, especially those not removed as the trees grow. The same symptoms were also found by Appleton (2006) and Glenn (1965). Glenn (1965) also found scratches and discolouration of the bark as a result of staking materials. Aboveground systems that are attached to the trunk with stiff metal wire prevent the natural increase in trunk diameter as the tree grows (Costello et al. 2003; Harris et al. 2004). The results are indentations in the trunk as the tree attempts to overcome the obstruction. Swelling results as the nutrients transported by the phloem are restricted and build up above the metal attachment (Johnson 1997; Costello et al. 2003; Harris et al. 2004).

TSSs were more strongly associated with good tree health on public property compared to those on private property. Public trees expressed fewer symptoms of diminished overall health, crown dieback, pests/diseases, stunted growth, and suckering than did trees on private property. Notably they did not suffer significantly more girdling or swelling even though they had a
TSS. Conversely, trees on private land observed with a TSS expressed severe swelling and girdling on their trunks, along with more crown dieback, than publicly owned trees with a TSS. These results indicate that land ownership (a cultural factor; Corry and Nassauer 2002) affects the susceptibility of trees to TSS effects and should be an added consideration for planting specifications. The cause of differences might be due to management practices on public and private lands. Trees on public lands are examined by City of Guelph staff approximately two years after transplant at a warranty inspection. They are inspected for tree health and establishment with the TSS removed prior to this inspection. Management and inspection of private lands with diverse land owners is unknown and no warranty inspection is known (none is required for site plan approval).

The authors conducted a deeper examination of the data to determine if management or location was the factor changing the susceptibility to TSS effects on public and private lands. Trees planted on public lands had a tendency to be in parks and stormwater management facilities, while trees on private property were often found in parking lots medians or located in close proximity to busy roads. Species composition was generally similar and appropriate to the planting locations, yet the variable conditions of the settings (medians versus water management facilities) complicates the interpretation of the results. The additional stress of the location of private trees may also increase the tree's susceptibility to TSS effects.

To consider land ownership and use and planting location effects (e.g., medians to stormwater management facilities), the study authors compared the health symptom scores of trees on public land with private institutional land. Private institutional land ownership/use had the most similar site characteristics to the public landscapes observed. Private institutional land uses were most like the public parks and storm water management sites in terms of openness and relatively undisturbed soil and drainage conditions; species selection was similar for private institutional and public sites. The two most common genera among public sites were Acer and Quercus (40\% of all trees). For private institutional sites, Acer and Quercus constituted $46 \%$ of all trees. However, Syringa and Pyrus were each $10 \%$ of private institutional trees and were not observed on public lands.

Trees with TSSs on private institutional land had lower health scores than those on public lands, indicating that management appears to be an important factor causing an increased susceptibility of trees to TSS effects. This has implications for ensuring the removal of TSSs as part of the construction documentation. Results from current research seem to suggest that stabilization systems benefit tree establishment and reduce transplant shock for symptoms of overall health and pest/disease. However, negative effects of TSSs are known to occur when TSSs remain on the tree after it has established in the landscape, exhibiting symptoms of a girdled trunk, trunk swelling, and wilting (Table 7). These symptoms worsen and impact the overall health of the tree. Management plays an important role in tree susceptibility to TSS effects and should be mandated with the installation of TSS.

Appleton (2006) found symptoms of girdling on tree trunks when TSSs were left on for two years; however, no significant damage was observed on trees with TSSs for one year. The current research also observed trunk damage on many trees when the TSS was apparently left on too long. While exact planting dates are not known (but inferred from site plan approval dates or war- 
Table 7. Results of comparisons of symptoms for sampled trees with and without stabilization systems, stratified by land ownership (Wilcoxon signed ranks test, $P=0.05$; public $n=247$, private $n=241$ ).

\begin{tabular}{|c|c|c|c|c|c|c|}
\hline Symptom & $\begin{array}{l}\text { Mean values } \\
\text { for public trees } \\
\text { with TSS }\end{array}$ & $\begin{array}{l}\text { Mean values } \\
\text { for public trees } \\
\text { without TSS }\end{array}$ & $\begin{array}{l}\text { Public trees } \\
P \text { value }\end{array}$ & $\begin{array}{l}\text { Mean values } \\
\text { for private } \\
\text { trees with TSS }\end{array}$ & $\begin{array}{l}\text { Mean values } \\
\text { for private trees } \\
\text { without TSS }\end{array}$ & $\begin{array}{l}\text { Private trees } \\
P \text { value }\end{array}$ \\
\hline Overall health & 5.00 & 4.78 & $<0.0001^{\mathrm{z}}$ & 4.94 & 4.93 & 0.8855 \\
\hline Girdled trunk & 4.83 & 4.72 & 0.1979 & 4.30 & 4.78 & $0.0026^{y}$ \\
\hline Swelling & 4.99 & 5.00 & 0.7729 & 4.45 & 4.98 & $<0.0001^{y}$ \\
\hline Pest/disease & 5.00 & 4.74 & $<0.0001^{z}$ & 4.99 & 4.64 & $0.0004^{z}$ \\
\hline Leaf scorch & 4.66 & 4.74 & 0.8048 & 4.80 & 4.84 & 0.1781 \\
\hline Stunted growth & 5.00 & 4.92 & $0.0003^{z}$ & 4.99 & 4.96 & 0.8003 \\
\hline Suckering & 4.99 & 4.92 & $0.0408^{z}$ & 4.72 & 4.82 & 0.5754 \\
\hline
\end{tabular}

${ }^{2}$ Significantly $(P=0.05)$ less severe on trees observed with a tree stabilization system.

${ }^{y}$ Significantly $(P=0.05)$ more severe on trees observed with a tree stabilization system.

Note: Trees on private land have no known warranty inspection and are maintained by private staff or contractor. Trees on public land have a warranty inspection at 24 months and removal of TSS is required. Public trees are maintained by city staff.

ranty periods), indications that the TSS was on too long were substantially rusted wire ties, hoses bleached from sun exposure, and loose metal stakes that were no longer tightly held in the ground. In some cases, plastic hose segments had shifted allowing the metal ties to form small indentations in the bark. The research concurs with Appleton (2006) and Brown (1987), indicating that when TSSs remain on the tree for too long, serious negative health effects can begin to develop. In fact, Brown (1987) shows in his research that damages caused by extended use of TSS may be occurring at the cellular level even if not visible noticeable to the naked eye.

\section{CONCLUSION}

In most cases, it was found that TSSs were associated with improved health during a short period (1-3 years) after transplant. However, management of TSSs affect tree damage. Trees planted on public land undergo a two-year warranty inspection where all TSS materials are removed (White, pers. comm.) and these trees were found to benefit from the use of a TSS. These trees expressed fewer symptoms of diminished overall health, crown dieback, pests/diseases, stunted growth, and suckering than trees without a TSS. Notably, they did not suffer significantly more girdling or swelling even though they had a TSS. Conversely, trees on private land, where management is unknown, expressed significantly poorer health for three out of four symptoms. Privately owned trees with a TSS had severe swelling and girdling on their trunks-along with more crown dieback - than trees without a TSS, vivid indications of TSSs left on the tree too long (Figure 2d).

Continuing research is needed to fully understand the health effects of TSSs on tree health. Other researchers have suggested the use of photodegradable or cloth-like materials for reducing girdling and swelling that might mitigate damages to trees with TSS that are not removed in a timely way (Ball et al. 1997; Appleton et al. 2008). The current research observed three TSS types, but all generally consisted of the same commonly-crafted tying materials (steel wire covered with garden hose segments). Biodegradable materials, such as burlap ties, should be explored for their effects on tree health as well as their capacity to provide adequate stabilization support because biodegradable materials may alleviate problems of the common types observed here. Timely tie degradation (in the event of inadequate maintenance of tying materials) might improve tree health.

\section{LITERATURE CITED}

Alvey, A., P.E. Wiseman, and B. Kane. 2009. Efficacy of conventional tree stabilization systems and their effect on short-term tree development. Arboriculture \& Urban Forestry 35(3):157-164

Appleton, B.L. 2006. Tree stabilization at transplant. SNA Research Conference 51:473-475.

Appleton, B.L., C. M. Cannella, P. E. Wiseman, and A. Alvey. 2008. Tree stabilization: current products and practices. Arboriculture \& Urban Forestry 34(1):54-58.

Ball, J., D. Williams, and P. Weicherding. 1997. Planting and maintenance of woody ornamental plants. pp. 39-61. In: J. Lloyd (Ed.). Plant Health Care for Woody Ornamentals: A Professional's Guide to Preventing and Managing Environmental Stresses and Pests. University of Illinois Board of Trustees and International Society of Arboriculture, Champaign, IL. 223 pp.

Bradley, G.A. (Ed.). 1995. Urban Forest Landscapes: Integrating Multidisciplinary Perspectives. University of Washington Press, Seattle, WA. $224 \mathrm{pp}$.

Brown, I.R. 1987. Suffering at the stake. pp. 85-90. In: D. Patch (Ed.). Advances in Practical Arboriculture. Forestry Commission Bulletin 65, HMSO, London, England.

Clark, J.R., and N. Matheny. 1991. Management of mature trees. Journal of Arboriculture 17(7):173-184.

Corry, R.C., and J.I. Nassauer. 2002. Managing for small-patch patterns in human-dominated landscapes: Cultural factors and Corn Belt agriculture. In: J. Liu and W. Taylor (Eds.). Integrating Landscape Ecology into Natural Resource Management. Cambridge University Press, Cambridge, Mass. pp. 92-113.

Costello, L.R., E.J. Perry, N.P. Matheny, M.J. Henry, and P.M. Geisel. 2003. Abiotic Disorders of Landscape Plants: A Diagnostic Guide. University of California Agriculture and Natural Resources, Oakland, CA. 242 pp.

Eckstein, R., and E.F. Gilman. 2008. Evaluation of landscape tree stabilization systems. Arboriculture \& Urban Forestry 34(4):216-221.

Gilman, E.F. 1997. Trees for Urban and Suburban Landscapes. Delmar Publishers, Albany, NY. 662 pp.

Glenn, E.M. 1965. A trial of tree ties. East Malling Research Station Annual Report 1964. pp. 200-202.

Harris, R.J., and N.L. Bassuk. 1993. Tree planting fundamentals. Journal of Arboriculture 19(2):64-70. 
Harris, R.W., and W.D. Hamilton. 1969. Staking and pruning young Myoporum laetum trees. Journal of American Society of Horticultural Science 94(4):359-361.

Harris, R.W. 1984. Effects of pruning and staking on landscape trees. Journal of Environmental Horticulture 2(4):140-142.

Harris, R.W., J. Clark, and N. Matheny. 2004. Arboriculture, Integrated Management of Landscape Trees, Shrubs, and Vines. Prentice Hall, Upper Saddle River, NJ. 578 pp.

Jacobs, M.R. 1954. The effect of wind sway on the form and development of Pinus radiata D. Don. Australian Journal of Botany 2(1):35-51.

Johnson, G. 1997. Diagnosing tree disorders. pp. 61-76. In: J. Lloyd. (Ed.). Plant Health Care for Woody Ornamentals: A Professional's Guide to Preventing and Managing Environmental Stresses and Pests. University of Illinois Board of Trustees and International Society of Arboriculture, Champaign, IL. 223 pp.

Moll, G. 1995. Urban forestry: A national initiative. pp. 12-16. In: G.A. Bradley (Ed.). Urban Forest Landscapes: Integrating Multidisciplinary Perspectives. University of Washington Press, Seattle, WA. $224 \mathrm{pp}$.

Leiser, A.T., R.W. Harris, P.L. Neel, D. Long, N.W. Stice, and R.G. Maire. 1972. Staking and pruning influence trunk development of young trees. Journal of American Society of Horticultural Science 97(4):498-503.

Lilly, S. 2001. Arborists' Certification Study Guide, 2nd Revised Edition. International Society of Arboriculture, Champaign, IL. 222 pp.

Patch, D. 1987. Trouble at the stake. In: D. Patch (Ed.). Advances in Practical Arboriculture. Forestry Commission Bulletin 65, HMSO, London, England. pp. 77-84.

Rahardjo, H., F.R. Harnas, E.C. Leong, P.Y. Tan, Y.K. Fong, and E.K. Sim. 2009. Tree stability in an improved soil to withstand wind loading. Urban Forestry and Urban Greening 8:237-247.

Struve, D.K. 2009. Tree Establishment: a review of some of the factors affecting transplant survival and establishment. Arboriculture \& Urban Forestry 35(1):10-13.

Svihra, P., D. Burger, and D. Ellis. 1999. Effects of 3 trunk support systems on growth of young Pyrus calleryana trees. Journal of Arboriculture 25(6):319-324.

Urban, J. 2008. Up By Roots: Healthy soils and trees in the built environment. International Society of Arboriculture, Champaign, IL. 479 pp.

White, H. 2009. Personal communication with Parks Planner Development and Parks Planning Community Design and Development Services City of Guelph. September 28, 2009.

Wrigley, M.P., and G.S. Smith. 1978. Staking and pruning effects on trunk and root development of four ornamental trees. New Zealand Journal of Environmental Agriculture 6:309-311.

\section{Kendra J. Labrosse \\ Landscape Architecture \\ University of Guelph \\ Ontario, Canada}

\author{
Robert C. Corry (corresponding author) \\ Landscape Architecture \\ University of Guelph \\ Ontario, Canada
}

Youbin Zheng

School of Environmental Sciences

University of Guelph

Ontario, Canada
Résumé. Un système de stabilisation des arbres est requis pour assurer la stabilité et maintenir la posture de l'arbre lors de la transplantation. Cependant, le tuteurage ou l'ancrage au sol peuvent compromettre la santé de l'arbre. Les auteurs de la présente étude ont approfondi les effets de ces systèmes de stabilisation sur l'arbre afin d'améliorer les normes techniques de plantation des arbres urbains. Les symptômes visuels de condition des arbres ont été enregistrés à partir de 488 arbres avec et sans système de stabilisation à Guelph en Ontario au Canada. Les résultats montrant des retard de croissance, de la mortalité et des problèmes de parasites étaient moins nombreux chez les arbres avec des système de stabilisation. La santé était négativement affectée par les systèmes de stabilisation sous la forme de plus de symptômes de troncs annelés, de tronc enflés et de flétrissure des feuilles. Les arbres plantés sur les terrains publics ont démontré qu'ils profitaient mieux de la présence d'un système de stabilisation tandis que les arbres sur terrains privés exprimaient plus d'effets négatifs avec ces systèmes. Les implications pour les professionnels en foresterie urbaine sont une limitation des pratiques de stabilisation des arbres en fonction des conditions du site et où leur emploi est garanti par leur enlèvement subséquent après une période fixe.

Zusammenfassung. Ein Stabilisierungssystem für Bäume (TSS) ist spezialisiert auf die Stabilität und Erhaltung der Pflanzposition während der Verpflanzung. Dennoch können die Stabilisatoren die Baumgesundheit beeinflussen. Die Autoren der gegenwärtigen Studie haben die Einflüsse von solchen Stabilisierungssystemenfür Bäume untersucht, um Empfehlungen für urbane Pflanzungen geben zu können. Es wurden die visuellen Merkmale für Baumgesundheit von 488 Bäumen mit oder ohne solche Systeme (TSS) in Guelph, Ontario, Canada gemessen. Die Ergebnisse zeigen an den Bäumen mit TSS weniger Symptome von Wachstumsverzögerungen, Absterben und Krankheiten. Die Gesundheit war aber bei verankerten Bäumen mehr veeinflusst durch Würgewurzeln, Schwellungen und Welke. Bäume auf öffentlichem Grund profitierten von der Stabilisierung, während in privatem Gelände die Bäume eher negative Auswirkungen auf ihre Gesundheit zeigten. Die daraus resultierenen Implikationen für urbane Forstleute schließen eine begrenzte Praxis zur Stabilisierung von Bäumen ein, wenn die Verwendung von solchen Systemen nicht zeitnah wieder entfernt wird.

Resumen. Se especifica un sistema de establecimiento de árboles (TSS) para promover la estabilidad y mantener la postura del árbol en el trasplante. Sin embargo, el estacado y el cableado pueden comprometer la salud del árbol. Los autores de este estudio han investigado los efectos de tales sistemas de estabilización con el fin de informar las especificaciones de la plantación. Los síntomas visuales para la salud del árbol fueron registrados para 488 árboles con y sin TSSs en Guelph, Ontario, Canadá. Los resultados que muestran síntomas de crecimiento atrofiado, muerte y plaga/enfermedad fueron menores en los árboles observados con TSSs. La salud estuvo negativamente impactada por TSSs con la producción de más síntomas de troncos afectados. Se encontró que los árboles plantados en áreas públicas aportan mayores beneficios que los ubicados en terrenos privados, cuando se encuentran estabilizados. Las implicaciones para los profesionales del bosque urbano incluyen limitaciones para las prácticas de estabilización de árboles en condiciones del sitio donde su uso está garantizado con remoción gradual. 